\title{
ENERGI DAN ZAT GIZI DALAM PENYELENGGARAAN MAKANAN DI TAMAN KANAK-KANAK DAN PERBANDINGANNYA TERHADAP SUBJEK TANPA PENYELENGGARAAN MAKANAN
}

\author{
(Energy and nutrient of food service in kindergarten and the comparation to samples \\ without food service)
}

\author{
Vieta Annisa Nurhidayati ${ }^{1 *}$, Drajat Martianto ${ }^{1}$, Tiurma Sinaga ${ }^{1}$ \\ ${ }^{1}$ Departemen Gizi Masyarakat, Fakultas Ekologi Manusia, Institut Pertanian Bogor, Bogor 16680
}

\begin{abstract}
The purpose of this study is to calculate the contribution of nutrient availability in kindergarten food service to the fulfillment of energy and nutrient requirements as well as to analyze the difference in energy and nutrient adequacy level of food consumption in a day between samples with and without food service. The study used comparative cross sectional study design with total of 80 samples that were divided into two groups by with and without food service. Consumption data of the samples were collected with a food recall method. Nutrients that meet the standards adequacy of nutrients in the menu was just calcium by $64.6 \%$ of availability. There was no difference in the level of adequacy of energy, protein, fat, carbohydrates, calcium, and vitamin $C$ in both groups ( $p>0.1)$, but differences in the level of adequacy of iron in both groups ( $<<0.1)$ was found.
\end{abstract}

Keywords: acceptance, availability of nutrients, food service, kindergarten children, nutrients adequacy level

\begin{abstract}
ABSTRAK
Tujuan penelitian adalah menghitung kontribusi pemenuhan tingkat kecukupan energi dan zat gizi dari ketersediaan menu penyelenggaraan makanan TK, dan juga menganalisis perbedaan tingkat kecukupan energi dan zat gizi konsumsi pangan sehari antara subjek yang mengikuti pelayanan makanan dengan tanpa pelayanan makanan. Penelitian menggunakan desain comparative cross sectional study dengan 80 subjek yang dibagi ke dalam dua kelompok dengan pelayanan makanan dan tanpa pelayanan makanan. Data konsumsi dikumpulkan dengan metode food recall. Zat gizi yang memenuhi standar kecukupan hanya kalsium sebesar $64,6 \%$. Tidak ada perbedaan pada tingkat kecukupan energi, protein, lemak, karbohidrat, kalsium, dan vitamin $\mathrm{C}$ pada kedua kelompok dengan atau tanpa penyelenggaraan makanan ( $>0,1)$, kecuali pada tingkat kecukupan zat besi $(p<0,1)$.
\end{abstract}

Kata kunci: anak TK, daya terima, ketersediaan zat gizi, pelayanan makanan, tingkat kecukupan zat gizi

\section{PENDAHULUAN}

Anak-anak pada usia sekolah melewati setidaknya seperempat waktu hariannya di sekolah. Waktu istirahat di sekolah biasanya digunakan untuk mengonsumsi makanan dalam rangka memenuhi kebutuhan energi dan zat gizi harian mereka. Konsumsi di sekolah tersebut berasal dari bekal dari rumah maupun jajanan di sekitar sekolah (Winarno dalam Aprillia 2011). Rahmi dan Muis (2005) dalam penelitiannya menunjukkan bahwa konsumsi jajanan di sekolah memberikan kontribusi terhadap asupan energi sebesar $22,9 \%$ dan protein $15,9 \%$. Briefel et al. (2009) dalam penelitiannya juga menunjukkan bahwa anak setidaknya mengabiskan waktu sebanyak 6 jam di sekolah dan mengonsumsi setidaknya $47 \%$ dari total asupan harian dari makanan dan selingan di sekolah. Kontribusi makanan di sekolah yang cukup besar terhadap pemenuhan kebutuhan anak sehari-hari menjadi potensi untuk memenuhi kebutuhan energi dan zat gizi anak. Besarnya kontribusi makanan di sekolah ini memiliki korelasi positif terhadap asupan zat

$\overline{\text { "Korespondensi: Telp: }}+8210-2840-1099$, Surel: vietaannisa@gmail.com 
gizi esensial pada anak dan juga memberi manfaat kesehatan tambahan dengan menyediakan buah-buahan segar, beragam sayur-sayuran, dan serealia lainnya (Condon et al. 2009).

Upaya untuk memenuhi kebutuhan energi dan zat gizi anak yang baik melalui konsumsi di sekolah dapat dilakukan dengan berbagai cara, salah satunya melalui pelayanan makanan. Tujuan penyelenggaraan makanan di sekolah pada dasarnya adalah untuk memenuhi kebutuhan siswa di sekolah, meningkatkan status gizi, dan meningkatkan kemampuan belajar siswa (Ishida 2015). Arteaga dan Heflin (2014) dalam penelitiannya juga menunjukkan bahwa program makan siang di taman kanak-kanak (TK) membantu mengurangi kerentanan pangan bagi anak yang berasal dari keluarga berpendapatan rendah. Hasil penelitian Jomaa et al. (2011) menunjukkan bahwa asupan energi dan zat gizi mikro serta angka kehadiran pada siswa penerima pelayanan makanan di sekolah lebih tinggi dibandingkan dengan siswa tanpa pelayanan makanan. Sinaga et al. (2012) pada penelitiannya menunjukkan bahwa, pemberian sarapan sepinggan pada siswa SD memberikan pengaruh nyata pada peningkatan asupan energi dan zat gizi siswa.

Waktu (TK) merupakan periode emas untuk pembentukan kebiasaan gizi dan berkorelasi positif pada performa akademik anak di sekolah dasar dan sekolah menengah (Arteaga \& Heflin 2014). Lynch (2015) menunjukkan bahwa program pengenalan gizi di TK masih berfokus pada edukasi gizi interaktif di kelas dan bukan pada intervensi pemberian makanan sehat secara langsung. Edukasi gizi di TK dalam berbagai penelitian berhasil meningkatkan pengetahuan gizi anak secara signifikan (Hu 2009; Hovland et al. 2012; Oh 2012). Berbagai jenis edukasi gizi yang banyak digunakan di TK antara lain program MyPlate (Osera 2016) serta program Building a Healthy Me (BHM) di California (Robertson 2016) yang meningkatkan pengetahuan anak tentang kelompok bahan makanan dan memperkaya preferensi makanan anak. Edukasi gizi tersebut hanya terbukti meningkatkan pengetahuan gizi anak namun tidak mengubah kebiasaan makan anak setelah program edukasi gizi dilaksanakan. Schindler et al. (2013) dalam penelitiannya menunjukkan bahwa hanya anak yang mendapatkan edukasi gizi beserta intervensi langsung yang menunjukkan kesediaan untuk terus mengonsumsi buah dan sayur sementara anak yang hanya mendapatkan edukasi gizi kembali kepada kebiasaan makan awal sebelum intervensi.

Pemerintah Indonesia telah melakukan Program Makanan Tambahan untuk Anak Seko- lah (PMT-AS) berdasarkan Instruksi Presiden No. 1 tahun 1997, dengan target utama adalah siswa SD/MI. Cakupan PMT-AS ini kemudian diperluas lagi dengan penambahan target anak TK/RA pada tahun 2011. Pelaksanaan PMTAS di TK juga mulai diikuti dengan munculnya program makan siang untuk anak TK. Sebanyak $15 \%$ dari 61 TK yang berada di Kota Sukabumi mulai menyediakan pelayanan makan siang untuk siswanya. Dua di antaranya menyelenggarakan makan siang dengan menu lengkap setiap harinya. Santoso dan Ranti (2004) menyebutkan salah satu fungsi dari pelaksanaan makan siang di TK adalah menyediakan konsumsi zat gizi anak. Pencapaian dari fungsi tersebut tidak terlepas dari penerapan menu yang sesuai dengan kebutuhan anak. Penelitian ini dilakukan untuk mengetahui kecukupan energi dan zat gizi dalam menu pelayanan makanan TK serta menganalisis perbedaan tingkat kecukupan energi dan zat gizi dalam sehari, antara subjek yang mengikuti pelayanan makanan dengan tanpa pelayanan makanan.

\section{METODE}

\section{Desain, tempat, dan waktu penelitian}

Penelitian ini merupakan comparative cross sectional study. Penelitian dilakukan di TK Daruttaqwa dengan pelayanan makanan dan TK Negeri Pembina Lembursitu, Kota Sukabumi untuk TK tanpa pelayanan makanan. Pemilihan tempat dilakukan secara purposive. Penelitian dilakukan pada bulan Januari sampai April 2015.

\section{Jumlah dan cara penarikan subjek}

Populasi dalam penelitian ini adalah anak yang bersekolah di TK Daruttaqwa dan TK Negeri Pembina Lembursitu. Pengambilan subjek dilakukan secara purposive sampling, dengan subjek penelitian adalah anak TK kelas B. Subjek dibagi menjadi dua kelompok yaitu anak dengan pelayanan makanan untuk TK Daruttaqwa dan anak tanpa pelayanan makanan untuk TK Negeri Pembina Lembursitu. Pengambilan jumlah subjek didasarkan pada perhitungan menggunakan rumus Slovin, yaitu $\mathrm{n}=\mathrm{N} /\left(1+\mathrm{N}(\mathrm{d})^{2}\right.$, dimana $\mathrm{n}$ adalah jumlah subjek, $\mathrm{N}$ merupakan jumlah populasi, dan d adalah tingkat kesalahan yang ditolerir (10\%).Hasil perhitungan jumlah minimal subjek untuk dua kelompok penelitian sejumlah 54 orang yang akan dibagi secara proporsional.

\section{Jenis dan cara pengumpulan data}

Data yang dikumpulkan meliputi data primer dan data sekunder. Data primer meliputi: 
1) karakteristik subjek (nama, umur, jenis kelamin, berat badan dan tinggi badan); 2) ketersediaan makanan yang disajikan oleh sekolah; 3) total konsumsi subjek satu hari; 4) tingkat kecukupan gizi subjek.

Karakteristik subjek didapatkan melalui pengisian kuesioner yang diberikan kepada orang tua. Karakteristik antropometri yang mencakup berat badan dan tinggi badan diukur secara langsung. Data berat badan diperoleh dengan penimbangan langsung menggunakan timbangan injak dengan ketelitian $0,1 \mathrm{~kg}$, data tinggi badan diperoleh dengan pengukuran langsung di lokasi menggunakan stature meter dengan ketelitian $0,1 \mathrm{~cm}$. Status gizi subjek ditentukan berdasarkan indeks masa tubuh menurut umur (IMT/U) yang mengacu pada Kepmenkes RI nomor 1995/ MENKES/SK/XII/2010 tentang standar antropometri penilaian status gizi anak.

Ketersediaan zat gizi dalam menu makan siang yang diberikan kepada anak, dihitung berdasarkan kandungan energi dan zat gizi dari berbagai bahan pangan komponen menu. Penilaian terhadap ketersediaan zat gizi dilakukan selama delapan hari sesuai dengan siklus menu delapan hari yang disajikan oleh katering. Ketersediaan makanan yang disediakan di sekolah diukur dengan penimbangan satu porsi makanan yang disajikan menggunakan timbangan digital dengan ketelitian $1 \mathrm{~g}$. Total konsumsi subjek dalam satu kali 24 jam dilakukan melalui metode food recall selama dua hari yaitu hari sekolah dan hari libur. Tingkat kecukupan zat gizi subjek dihitung dengan cara membandingkan total konsumsi sehari subjek dengan angka kecukupan gizinya.

\section{Pengolahan dan analisis data}

Pengolahan data menggunakan Microsoft Excel 2012, dan dianalisis lebih lanjut menggunakan SPSS 16.0 for Windows. Data karakteristik subjek terdiri atas jenis kelamin, usia, dan status gizi. Data jumlah makanan yang disajikan dan dikonsumsi dari sekolah serta dari luar sekolah dikonversikan ke dalam bentuk energi, protein, lemak, karbohidrat, kalsium, zat besi, dan vitamin C menggunakan Daftar Komposisi Bahan Makanan (DKBM) serta label gizi untuk makanan kemasan. Tingkat ketersediaan energi dan zat gizi dari makanan yang disediakan oleh sekolah dihitung dengan cara membandingkan ketersediaan energi dan zat gizi makanan yang disediakan dengan kebutuhan gizi subjek berdasarkan AKG untuk Indonesia tahun 2014. Tingkat kecukupan energi dan zat gizi dihitung dengan membandingkan total konsumsi energi dan zat gizi dalam sehari dengan angka kecukupan zat gizi yang dianjurkan menurut umur. Tingkat kecukupan zat gizi makro diperoleh dengan menggunakan cut-off point Depkes (1996) yang dibedakan menjadi defisit tingkat berat $(<70 \%)$, defisit tingkat sedang (70-79\%), defisit tingkat ringan $(80-89 \%)$, normal $(90-119 \%)$, dan kelebihan $(>120 \%)$. Tingkat kecukupan zat gizi mikro diperoleh dengan menggunakan cut-off point Gibson (2005) yang dibedakan menjadi kurang $(<77)$ dan cukup ( $\geq 77)$.

Data dianalisis secara deskriptif dan inferensia. Normalitas sebaran data diuji terlebih dahulu dengan uji Kolmogorov-Smirnov. Analisis deskriptif dilakukan untuk data karakteristik subjek serta data tingkat kecukupan energi dan zat gizi subjek. Analisis inferensia Mann-Whitney digunakan untuk mengetahui signifikansi perbedaan karakteristik dan perbedaan tingkat kecukupan energi dan zat gizi antara kelompok subjek dengan sebaran data tidak normal.

\section{HASIL DAN PEMBAHASAN}

\section{Karakteristik subjek}

Karakteristik subjek dapat dilihat pada Tabel 1. Sebagian besar subjek penelitian berusia 6 tahun pada kedua kelompok penelitian. Kelompok dengan pelayanan makanan memiliki lebih banyak subjek berjenis kelamin perempuan, sedangkan kelompok tanpa pelayanan lebih banyak

Tabel 1. Karakteristik subjek penelitian

\begin{tabular}{lcccccc}
\hline $\begin{array}{c}\text { Karakteristik } \\
\text { subjek }\end{array}$ & $\begin{array}{c}\text { Subjek } \\
\text { dengan } \\
\text { pelayanan }\end{array}$ & \multicolumn{2}{c}{$\begin{array}{c}\text { Subjek } \\
\text { tanpa } \\
\text { pelayanan }\end{array}$} & \multicolumn{2}{l}{ Total } \\
\cline { 2 - 7 } & $\mathrm{n}$ & $\%$ & $\mathrm{n}$ & $\%$ & $\mathrm{n}$ & $\%$ \\
\hline Usia & & & & & & \\
6 tahun & 41 & 95,3 & 35 & 94,6 & 76 & 95 \\
7 tahun & 2 & 4,7 & 2 & 5,4 & 4 & 5 \\
Total & 43 & 100 & 37 & 100 & 80 & 100 \\
& & $\mathrm{p}=0,878$ & & & \\
Jenis Kelamin & & & & & & \\
Perempuan & 22 & 51,2 & 18 & 48,6 & 40 & 50 \\
Laki-laki & 21 & 48,8 & 19 & 51,4 & 40 & 50 \\
Total & 43 & 100 & 37 & 100 & 80 & 100 \\
& & $\mathrm{p}=0,824$ & & & \\
Status Gizi & & & & & & \\
Kurus & 2 & 4,7 & 3 & 8,1 & 5 & 6,2 \\
Normal & 36 & 83,7 & 30 & 81,1 & 66 & 82,5 \\
Gemuk & 3 & 7,0 & 3 & 8,1 & 6 & 7,5 \\
Obesitas & 2 & 4,7 & 1 & 2,7 & 3 & 3,8 \\
Total & 43 & 100 & 37 & 100 & 80 & 100 \\
& & $\mathrm{p}=0,641$ & & & \\
\hline
\end{tabular}


Nurhidayati dkk.

Tabel 2. Ketersediaan energi dan zat gizi menu makan siang TK

\begin{tabular}{lccccccc}
\hline Siklus & $\begin{array}{c}\text { Energi } \\
(\mathrm{kkal})\end{array}$ & $\begin{array}{c}\text { Protein } \\
(\mathrm{g})\end{array}$ & $\begin{array}{c}\text { Lemak } \\
(\mathrm{g})\end{array}$ & $\begin{array}{c}\text { Karbohidrat } \\
(\mathrm{g})\end{array}$ & $\begin{array}{c}\text { Kalsium }(\mathrm{Ca}) \\
(\mathrm{mg})\end{array}$ & $\begin{array}{c}\text { Besi }(\mathrm{Fe}) \\
(\mathrm{mg})\end{array}$ & $\begin{array}{c}\text { Vitamin C } \\
(\mathrm{mg})\end{array}$ \\
\hline Hari Ke-1 & 345 & 11,3 & 13,4 & 43,5 & 176,6 & 3,2 & 9,4 \\
Hari Ke-2 & 405 & 9,3 & 14,2 & 59,9 & 32,8 & 1,6 & 2,0 \\
Hari Ke-3 & 330 & 9,6 & 13,1 & 45,0 & 57,0 & 1,1 & 2,1 \\
Hari Ke-4 & 280 & 5,5 & 7,5 & 48,5 & 60,4 & 2,1 & 37,7 \\
Hari Ke-5 & 315 & 7,3 & 10,2 & 47,6 & 97,7 & 2,2 & 6,6 \\
Hari Ke-6 & 352 & 6,0 & 7,9 & 62,6 & 15,4 & 0,8 & 3,2 \\
Hari Ke-7 & 255 & 4,2 & 3,4 & 53,3 & 26,9 & 1,1 & 12,5 \\
Hari Ke-8 & 365 & 10,0 & 13,4 & 50,4 & 49,7 & 1,9 & 16,2 \\
\hline Rata-rata \pm SD & $331 \pm 48$ & $7,9 \pm 2,5$ & $10,4 \pm 3,8$ & $51,4 \pm 6,9$ & $64,6 \pm 51,8$ & $1,8 \pm 0,8$ & $11,2 \pm 11,9$ \\
\hline min-max & $255-405$ & $4,2-11,3$ & $3,4-14,2$ & $43,5-62,6$ & $15,4-176,6$ & $0,8-3,2$ & $2,0-37,7$ \\
\hline
\end{tabular}

subjek berjenis kelamin laki-laki. Sebagian besar subjek memiliki status gizi normal yaitu sebanyak $83,7 \%$ pada kelompok pelayanan makanan, sebanyak $81,1 \%$ pada kelompok tanpa pelayanan makanan. Kelompok dengan pelayanan makanan memiliki subjek dengan status gizi obesitas lebih banyak dibandingkan kelompok tanpa pelayanan makanan sebanyak $4,7 \%$. Karakteristik jenis kelamin, usia maupun status gizi kelompok dengan pelayanan makanan dan kelompok tanpa pelayanan tidak memiliki perbedaan nyata $(\mathrm{p}>$ $0,1)$.

\section{Ketersediaan zat gizi}

Hasil perhitungan terhadap ketersediaan energi dan zat gizi setiap menu pada Tabel 2, menunjukkan belum adanya keseragaman kandungan gizi dari setiap menu makan siang. Khan dalam Sinaga (2007) menyatakan bahwa, ketersediaan makan siang yang diberikan di sekolah setidaknya harus memenuhi $1 / 3$ kebutuhan gizi anak dalam sehari. Pemerintah Jepang dalam Tanaka dan Miyoshi (2012) menetapkan secara langsung jumlah kandungan energi dan zat gizi yang harus disajikan setiap kali makan siang berdasarkan kelompok umur anak. Subjek dengan pelayanan makanan memiliki rata-rata kebutuhan energi $1.587 \mathrm{kkal}$, protein $34,9 \mathrm{~g}$, lemak 61,5 g, karbohidrat 218,3 g, kalsium $100 \mathrm{mg}$, zat besi $9 \mathrm{mg}$, serta vitamin C $45 \mathrm{mg}$. Hasil perbandingan antara rata-rata ketersediaan energi dan zat gizi yang disediakan dengan standar ditunjukkan pada Tabel 3 .

Tabel 3 menunjukkan bahwa rata-rata ketersediaan energi dan zat gizi yang diberikan dalam satu porsi makan siang TK Daruttaqwa, belum memenuhi standar gizi untuk makan siang berdasarkan standar dari Khan (Sinaga 2007) maupun Pemerintah Jepang (Tanaka \& Miyoshi 2012). Zat gizi yang sudah memenuhi standar ketersediaan per makan siang dari Khan adalah kalsium $(64,6 \%)$ dengan seringnya pemberian yoghurt dan sayuran hijau sebagai kontributor ketersediaan kalsium dalam menu. Akan tetapi, ketersediaan kalsium tersebut belum memenuhi standar yang ditetapkan Pemerintah Jepang sebesar $300 \mathrm{mg}$. Ketersediaan lemak dan protein dari menu masih sangat kurang, yaitu sebesar 7,9 g

Tabel 3. Perbandingan ketersediaan zat gizi dengan standar kandungan gizi

\begin{tabular}{lcccc}
\hline \multicolumn{1}{c}{ Zat Gizi } & $\begin{array}{c}\text { Rata-rata ketersediaan } \\
\text { energi \& zat gizi }\end{array}$ & $\begin{array}{c}\text { Rata-rata kebutuhan } \\
\text { subjek dalam sehari }\end{array}$ & $\begin{array}{c}\text { Standar kand. energi } \\
\text { \& zat gizi Khan }\end{array}$ & $\begin{array}{c}\text { Standar kand. energi \& zat gizi } \\
\text { Pemerintah Jepang }^{\mathrm{b}}\end{array}$ \\
\hline Energi (kkal) & 331 & 1587 & 476 & 560 \\
Protein (g) & 7,9 & 34,9 & 10,5 & 16 \\
Lemak (g) & 10,4 & 61,5 & 18,5 & 16 \\
Karbohidrat (g) & 51,4 & 218,3 & 65,5 & - \\
Kalsium (mg) & 64,6 & 100,0 & 30 & 300 \\
Zat besi (mg) & 1,8 & 9,0 & 2,7 & 3 \\
Vitamin C (mg) & 11,2 & 45,0 & 13,5 & 20 \\
\hline a Sinaga $207 \cdot$ bTana dan Miyoshi2012 & &
\end{tabular}


untuk protein dan 10,4 g untuk lemak. Hal tersebut dipengaruhi oleh tidak selalu diberikannya protein hewani dalam menu setiap siklus menu, dan porsi untuk protein hewani masih sedikit.Terdapat satu hari dari siklus menu delapan hari yang tidak menyertakan sumber protein hewani dalam penyediaan makan siang, rata-rata penyediaan protein hewani dalam satu porsi adalah sebesar setengah satuan penukar ( $25 \mathrm{~g}$ untuk ayam, 30 $\mathrm{g}$ untuk rolade daging, $20 \mathrm{~g}$ untuk cumi tepung). Rata-rata porsi nasi yang diberikan dalam satu kali makan siang adalah 80 gram, yaitu hanya $20 \%$ dari anjuran porsi nasi sehari untuk anak usia 6 tahun sebanyak 400 gram dari Kemenkes (2014).

Ketersediaan menu makan siang belum mencukupi karena perencanaan menu dan porsi makanan belum mempertimbangkan kebutuhan gizi anak. Hal tersebut juga mempengaruhi adanya variasi yang besar antara ketersediaan energi dan zat gizi pada masing-masing siklus menu. Salah satu upaya yang dapat dilakukan untuk memenuhi kebutuhan gizi anak dalam pemberian makan siang adalah dengan menetapkan komposisi bahan pangan serta pola makan dalam setiap menu (Ishida 2015). Komposisi menu yang diberikan untuk anak sebaiknya disesuaikan dengan pedoman gizi seimbang dan porsinya disesuaikan dengan anjuran porsi makanan untuk anak usia 5-6 tahun (Kemenkes 2014). Lee et al. (2006) menemukan bahwa hanya $7 \%$ katering untuk anak yang mempekerjakan ahli gizi, sementara sebagian besar lainnya melakukan perencanaan kegizian kepada tenaga non-profesional. Lee et al. (2006) juga menyarankan agar pelaksanaan administrasi katering dilakukan oleh ahli gizi, sehingga pelaksanaan makan siang di sekolah dapat sesuai dengan tujuan yang ingin dicapai.

Tujuan utama pelaksanaan makan siang di sekolah adalah untuk meningkatkan kesehatan anak serta membentuk pola makan yang sehat (Woo 2015). Pelaksanaan makan siang di sekolah yang sesuai dengan kebutuhan anak terbukti telah memiliki manfaat bagi pola makan anak. Spence et al. (2013) dalam penelitiannya menunjukkan bahwa makan siang di sekolah memiliki banyak keuntungan gizi dibandingkan bekal dari rumah, serta berpotensi mengurangi kejadian obesitas pada anak. Farris et al. (2014) juga menyatakan hal serupa bahwa bekal dari rumah memiliki kandungan gizi yang lebih rendah dibandingkan makan siang yang disediakan di TK terutama protein, natrium, serat, vitamin A, dan kalsium. Sebanyak $<15 \%$ anak usia taman kanak kanak mengonsumsi buah dan sayur sesuai jumlah yang dianjurkan (Schindler et al. 2013). Evans et al. (2012) dalam penelitiannya menunjukkan bahwa intervensi makan siang di sekolah dapat meningkatkan asupan buah dan sayur pada anak-anak.

\section{Tingkat kecukupan energi dan zat gizi}

Penilaian tingkat kecukupan energi dan zat gizi subjek dilakukan pada hari sekolah maupun hari libur. Tingkat kecukupan energi dan zat gizi subjek pada hari sekolah ditunjukkan pada Tabel 4 . Sebesar $30,2 \%$ subjek dengan pelayanan makanan, masih memiliki tingkat kecukupan energi defisit tingkat berat. Hal tersebut dipengaruhi oleh pola konsumsi kelompok subjek dengan pelayanan makanan yang jarang mengonsumsi selingan atau jajanan selain makanan utama. Meskipun kelompok subjek tanpa pelayanan sebagian besarnya telah memiliki tingkat kecukupan energi kategori normal, tetapi asupan energi sebagian besar berasal dari konsumsi lemak dari selingan dan jajanan. Kelompok subjek tanpa pelayanan makanan juga sebagian besar memiliki tingkat kecukupan protein, karbohidrat, dan zat gizi mikro yang kurang dibandingkan dengan subjek dengan pelayanan. Hal ini menunjukkan bahwa penyelenggaraan makanan di sekolah memiliki dampak positif dalam pemenuhan tingkat kecukupan energi dan zat gizi pada anak.

Perbandingan terhadap kedua subjek penelitian pada Tabel 4 menunjukkan bahwa subjek dengan pelayanan makanan cenderung memiliki tingkat kecukupan energi dan zat gizi yang lebih baik dibandingkan subjek tanpa pelayanan makanan. Hal tersebut menunjukkan bahwa makan siang sekolah membantu meningkatkan konsumsi energi dan zat gizi subjek. Perbedaan tingkat kecukupan antara kedua subjek terlihat pada tingkat kecukupan karbohidrat, subjek dengan pelayanan makanan sebagian besar (44,2\%) termasuk ke dalam kategori normal sedangkan subjek tanpa pelayanan makanan sebagian besar $(97,3 \%)$ termasuk ke dalam kategori defisit tingkat sedang. Santoso dan Ranti (2004) menyatakan bahwa, penyelenggaraan makanan di sekolah seringkali membuat anak yang sulit makan lebih mudah menerima makanan karena suasana lingkungan sekolah dan adanya teman saat mengonsumsi makanan. Rakhmawati (2009) dalam penelitiannya juga menunjukkan bahwa, kontribusi makanan di sekolah pada kelompok dengan pelayanan makanan lebih tinggi dibandingkan kelompok tanpa pelayanan makanan, yaitu energi sebesar 37,9\% untuk subjek dengan penyelenggaraan makanan dan energi sebesar $18,8 \%$ untuk subjek tanpa penyelenggaraan 
Nurhidayati dkk.

Tabel 4. Tingkat kecukupan energi dan zat gizi subjek pada hari sekolah

\begin{tabular}{|c|c|c|c|c|c|c|c|}
\hline \multirow{2}{*}{\multicolumn{2}{|c|}{ Tingkat kecukupan }} & \multicolumn{2}{|c|}{ Subjek dengan pelayanan } & \multicolumn{2}{|c|}{ Subjek tanpa pelayanan } & \multirow{2}{*}{ Jumlah } & \multirow{2}{*}{$\%$} \\
\hline & & $\mathrm{n}$ & $\%$ & $\mathrm{n}$ & $\%$ & & \\
\hline \multirow{7}{*}{ Energi } & Defisit tingkat berat & 13 & 30,2 & 7 & 18,9 & 20 & 25 \\
\hline & Defisit tingkat sedang & 5 & 11,6 & 2 & 5,4 & 7 & 8,7 \\
\hline & Defisit tingkat ringan & 5 & 11,6 & 5 & 13,5 & 10 & 12,5 \\
\hline & Normal & 19 & 44,2 & 17 & 45,9 & 36 & 45 \\
\hline & Kelebihan & 1 & 2,3 & 6 & 16,2 & 7 & 8,8 \\
\hline & Total & 43 & 100 & 37 & 100 & 80 & 100 \\
\hline & \multicolumn{7}{|c|}{$\mathrm{p}=0,359$} \\
\hline \multirow{7}{*}{ Protein } & Defisit tingkat berat & 4 & 9,3 & 24 & 64,9 & 28 & 35 \\
\hline & Defisit tingkat sedang & 8 & 18,6 & 3 & 8,1 & 11 & 13,8 \\
\hline & Defisit tingkat ringan & 5 & 11,6 & 4 & 10,8 & 9 & 11,2 \\
\hline & Normal & 11 & 25,6 & 5 & 13,5 & 16 & 20 \\
\hline & Kelebihan & 15 & 34,9 & 1 & 2,7 & 16 & 20 \\
\hline & Total & 43 & 100 & 37 & 100 & 80 & 100 \\
\hline & \multicolumn{7}{|c|}{$\mathrm{p}=0,330$} \\
\hline \multirow{7}{*}{ Lemak } & Defisit tingkat berat & 25 & 58,1 & 10 & 27,0 & 35 & 43,8 \\
\hline & Defisit tingkat sedang & 5 & 11,6 & 4 & 10,8 & 9 & 11,2 \\
\hline & Defisit tingkat ringan & 4 & 9,3 & 5 & 13,5 & 9 & 11,2 \\
\hline & Normal & 7 & 16,3 & 16 & 43,2 & 23 & 28,8 \\
\hline & Kelebihan & 2 & 4,7 & 2 & 5,4 & 4 & 5 \\
\hline & Total & 43 & 100 & 37 & 100 & 80 & 100 \\
\hline & \multicolumn{7}{|c|}{$\mathrm{p}=0,540$} \\
\hline \multirow{7}{*}{ Karbohidrat } & Defisit tingkat berat & 12 & 27,9 & 1 & 2,7 & 13 & 16,2 \\
\hline & Defisit tingkat sedang & 4 & 9,3 & 36 & 97,3 & 40 & 50 \\
\hline & Defisit tingkat ringan & 6 & 14,0 & 0 & 0 & 6 & 7,5 \\
\hline & Normal & 19 & 44,2 & 0 & 0 & 19 & 23,8 \\
\hline & Kelebihan & 2 & 4,7 & 0 & 0 & 2 & 2,5 \\
\hline & Total & 43 & 100 & 37 & 100 & 80 & 100 \\
\hline & \multicolumn{7}{|c|}{$\mathrm{p}=0,971$} \\
\hline \multirow{4}{*}{ Kalsium } & Kurang & 0 & 0 & 18 & 48,6 & 18 & 22,5 \\
\hline & Cukup & 43 & 100 & 19 & 51,4 & 62 & 77,5 \\
\hline & Total & 43 & 100 & 37 & 100 & 80 & 100 \\
\hline & \multicolumn{7}{|c|}{$\mathrm{p}=0,281$} \\
\hline \multirow{4}{*}{ Zat besi } & Kurang & 13 & 30,2 & 18 & 48,6 & 31 & 38,8 \\
\hline & Cukup & 30 & 69,8 & 19 & 51,4 & 49 & 61,2 \\
\hline & Total & 43 & 100 & 37 & 100 & 80 & 100 \\
\hline & \multicolumn{7}{|c|}{$\mathrm{p}=0,094$} \\
\hline \multirow{4}{*}{ Vitamin C } & Kurang & 31 & 72,1 & 30 & 81,1 & 61 & 76,2 \\
\hline & Cukup & 12 & 27,9 & 7 & 18,9 & 19 & 23,8 \\
\hline & Total & 43 & 100 & 37 & 100 & 80 & 100 \\
\hline & \multicolumn{7}{|c|}{$\mathrm{p}=0,349$} \\
\hline
\end{tabular}

makanan. Adapun rata-rata kontribusi makan siang anak di sekolah terhadap pemenuhan kecukupan energi sehari dalam penelitian ini adalah sebesar 20,9\% (16,1-25,5\%). Kontribusi tersebut juga berdampak pada tingkat kecukupan ener- gi dan zat gizi yang lebih tinggi pada kelompok dengan pelayanan makanan.

Perbandingan antara tingkat kecukupan energi dan zat gizi subjek menunjukkan bahwa kelompok dengan pelayanan makanan cenderung 
Kecukupan energi dan zat gizi penyelenggaraan makanan TK

Tabel 5. Tingkat kecukupan energi dan zat gizi subjek pada hari libur

\begin{tabular}{|c|c|c|c|c|c|c|c|}
\hline \multirow{2}{*}{\multicolumn{2}{|c|}{ Tingkat Kecukupan }} & \multicolumn{2}{|c|}{ Subjek dengan pelayanan } & \multicolumn{2}{|c|}{ Subjek tanpa pelayanan } & \multirow{2}{*}{ Jumlah } & \multirow{2}{*}{$\%$} \\
\hline & & $\mathrm{n}$ & $\%$ & $\mathrm{n}$ & $\%$ & & \\
\hline \multirow{7}{*}{ Energi } & Defisit tingkat berat & 13 & 30,2 & 7 & 18,9 & 20 & 25 \\
\hline & Defisit tingkat sedang & 12 & 27,9 & 5 & 13,5 & 17 & 21,2 \\
\hline & Defisit tingkat ringan & 7 & 16,3 & 8 & 21,6 & 15 & 18,8 \\
\hline & Normal & 7 & 16,3 & 5 & 24,3 & 16 & 20 \\
\hline & Kelebihan & 4 & 9,3 & 8 & 21,6 & 12 & 15 \\
\hline & Total & 43 & 100 & 37 & 100 & 80 & 100 \\
\hline & \multicolumn{7}{|c|}{$\mathrm{p}=0,897$} \\
\hline \multirow{7}{*}{ Protein } & Defisit tingkat berat & 5 & 11,6 & 26 & 70,3 & 31 & 38,8 \\
\hline & Defisit tingkat sedang & 5 & 11,6 & 2 & 5,4 & 7 & 8,7 \\
\hline & Defisit tingkat ringan & 2 & 4,7 & 6 & 16,2 & 8 & 10 \\
\hline & Normal & 21 & 48,8 & 3 & 8,1 & 24 & 30 \\
\hline & Kelebihan & 10 & 23,3 & 0 & 0 & 10 & 12,5 \\
\hline & Total & 43 & 100 & 37 & 100 & 80 & 100 \\
\hline & \multicolumn{7}{|c|}{$\mathrm{p}=0,144$} \\
\hline \multirow{7}{*}{ Lemak } & Defisit tingkat berat & 25 & 58,1 & 12 & 32,4 & 37 & 46,2 \\
\hline & Defisit tingkat sedang & 5 & 11,6 & 5 & 13,5 & 10 & 12,5 \\
\hline & Defisit tingkat ringan & 4 & 9,3 & 7 & 18,9 & 11 & 13,8 \\
\hline & Normal & 6 & 14,0 & 13 & 35,1 & 19 & 23,8 \\
\hline & Kelebihan & 3 & 7,0 & 0 & 0 & 3 & 3,7 \\
\hline & Total & 43 & 100 & 37 & 100 & 80 & 100 \\
\hline & \multicolumn{7}{|c|}{$p=0,206$} \\
\hline \multirow{7}{*}{ Karbohidrat } & Defisit tingkat berat & 16 & 37,2 & 3 & 8,1 & 19 & 23,8 \\
\hline & Defisit tingkat sedang & 4 & 9,3 & 34 & 91,9 & 38 & 47,5 \\
\hline & Defisit tingkat ringan & 10 & 23,3 & 0 & 0 & 10 & 12,5 \\
\hline & Normal & 10 & 23,3 & 0 & 0 & 10 & 12,5 \\
\hline & Kelebihan & 3 & 7,0 & 0 & 0 & 3 & 3,7 \\
\hline & Total & 43 & 100 & 37 & 100 & 80 & 100 \\
\hline & \multicolumn{7}{|c|}{$\mathrm{p}=0,837$} \\
\hline \multirow{4}{*}{ Kalsium } & Kurang & 2 & 4,7 & 24 & 64,9 & 26 & 32,5 \\
\hline & Cukup & 41 & 95,3 & 13 & 35,1 & 54 & 67,5 \\
\hline & Total & 43 & 100 & 37 & 100 & 80 & 100 \\
\hline & \multicolumn{7}{|c|}{$\mathrm{p}=0,527$} \\
\hline \multirow{4}{*}{ Zat Besi } & Kurang & 16 & 37,2 & 24 & 64,9 & 40 & 50 \\
\hline & Cukup & 27 & 62,8 & 13 & 35,1 & 40 & 50 \\
\hline & Total & 43 & 100 & 37 & 100 & 80 & 100 \\
\hline & \multicolumn{7}{|c|}{$\mathrm{p}=0,014$} \\
\hline \multirow{4}{*}{ Vitamin C } & Kurang & 33 & 76,7 & 31 & 83,8 & 64 & 80 \\
\hline & Cukup & 10 & 23,3 & 6 & 16,2 & 16 & 20 \\
\hline & Total & 43 & 100 & 37 & 100 & 80 & 100 \\
\hline & \multicolumn{7}{|c|}{$\mathrm{p}=0,435$} \\
\hline
\end{tabular}

memiliki tingkat kecukupan yang lebih baik, tetapi hasil uji Mann-Whitney menunjukkan bahwa, tidak ada perbedaan yang nyata antara tingkat kecukupan energi, protein, lemak, karbohidrat, kalsium, serta vitamin $\mathrm{C}$ antara kedua kelompok $(\mathrm{p}>0,1)$. Tingkat kecukupan zat besi antara kedua kelompok subjek pada hari sekolah memiliki perbedaan nyata $(\mathrm{p}<0,1)$. 
Perbedaan tingkat kecukupan energi dan zat gizi pada hari libur tidak terlihat pada kedua kelompok subjek pada Tabel 5. Hasil uji menunjukkan bahwa tidak ada perbedaan yang nyata antara tingkat kecukupan energi, protein, lemak, karbohidrat, kalsium, serta vitamin $\mathrm{C}$ antara kedua kelompok subjek pada hari libur $(\mathrm{p}>0,1)$, tetapi tingkat kecukupan zat besi antara kedua kelompok subjek memiliki perbedaan nyata $(\mathrm{p}<0,1)$. Tingkat kecukupan energi dan zat gizi kelompok subjek dengan pelayanan makanan mengalami penurunan, jika dibandingkan dengan hari sekolah. Hal tersebut dipengaruhi oleh berkurangnya asupan yang berasal dari makan siang yang disediakan sekolah, serta pola makan kelompok subjek dengan pelayanan yang jarang mengonsumsi selingan atau jajanan. Hal ini menunjukkan bahwa saat hari libur, anak kembali ke pola makan harian di rumah tanpa intervensi dari penyelenggaraan makanan di sekolah sehingga kedua kelompok tidak memiliki perbedaan dalam tingkat kecukupan energi dan zat gizi. Penemuan ini juga menegaskan kembali kontribusi penyelenggaraan makanan dalam pemenuhan kecukupan energi dan zat gizi anak.

Tingkat kecukupan energi dan zat gizi subjek pada kedua kelompok pada hari libur masih banyak masuk ke dalam kategori defisit dan kurang. Santoso dan Ranti (2004) menyatakan bahwa kondisi gizi yang sering terjadi pada anak adalah kekurangan konsumsi energi, protein, vitamin A, yodium, dan zat besi. Keadaan tersebut dipengaruhi oleh kondisi dan anggapan orang tua yang merugikan penyajian makanan untuk anak. Kondisi tersebut diantaranya adalah penyajian makanan masih perlu diadaptasi, karena anak masih dalam proses transisi dari makanan bayi ke makanan dewasa, serta pengasuhan anak tidak diperhatikan lagi dan biasanya diserahkan kepada orang lain termasuk masalah makanan. Kondisi-kondisi tersebut memungkinkan tidak terpenuhinya kebutuhan energi dan zat gizi anak dari konsumsi selama di rumah.

Hasil uji menunjukkan bahwa tingkat kecukupan zat gizi yang memiliki perbedaan nyata pada kedua kelompok subjek penelitian hanya zat besi. Hal ini berbeda dengan hasil penelitian Rakhmawati (2009), yang menunjukkan adanya perbedaan nyata antara tingkat kecukupan energi, vitamin $\mathrm{C}$, dan kalsium pada kelompok subjek dengan pelayanan makanan dengan kelompok subjek tanpa pelayanan makanan pada siswa sekolah dasar. Perbedaan nyata pada tingkat kecukupan zat besi terjadi karena kelompok dengan pelayanan makanan cenderung mengonsumsi sumber zat besi lebih baik dibandingkan kelom- pok tanpa pelayanan makanan seperti daging, susu, bayam, serta daun katuk.

Kelompok dengan penyelenggaraan makanan memiliki rata-rata tingkat kecukupan zat besi sebesar $96,2 \%$ pada hari sekolah dan $95,2 \%$ pada hari libur. Sedangkan kelompok tanpa penyelenggaraan makanan memiliki ratarata tingkat kecukupan zat besi sebesar $87,8 \%$ pada hari sekolah dan 78,7\% pada hari libur. Perbedaan jumlah subjek yang termasuk ke dalam kategori cukup untuk tingkat kecukupan zat besi juga dapat dilihat pada Tabel 4 dan Tabel 5 dimana subjek dengan pelayanan makanan memiliki frekuensi yang lebih tinggi dibandingkan dengan kelompok tanpa penyelenggaraan makanan.

Kedua kelompok subjek sebagian besar memiliki tingkat kecukupan vitamin $\mathrm{C}$ yang kurang pada hari sekolah maupun hari libur. Hal tersebut dipengaruhi oleh kurangnya konsumsi buah dan sayur pada anak usia sekolah (Mohammad \& Madanijah 2015). Kondisi tersebut dapat diperbaiki dengan pemberian buah sebagai dessert pada menu makan siang pada kelompok pelayanan makanan. Upaya lain yang dapat dilakukan adalah, dengan memberikan pendidikan gizi terkait jenis dan manfaat buah dan sayur kepada anak-anak pada kegiatan belajar mengajar.

\section{KESIMPULAN}

Rata-rata ketersediaan energi dan zat gizi dalam menu yang disajikan dari penyelenggaraan makanan masih belum memenuhi kebutuhan dari energi dan zat gizi subjek. Zat gizi yang memenuhi standar ketersediaan makan siang subjek adalah kalsium, karena seringnya penggunaan sayuran hijau dan yoghurt dalam menu. Rata-rata kontribusi pemenuhan energi dari penyelenggaraan makan siang adalah sebesar $20,9 \%$ terhadap kebutuhan harian anak. Tidak terdapat perbedaan nyata antara tingkat kecukupan energi, protein, lemak, karbohidrat, kalsium, dan vitamin $\mathrm{C}$ antara kedua kelompok subjek penelitian. Perbedaan nyata ditemukan pada tingkat kecukupan zat besi antara kedua kelompok subjek penelitian, karena subjek dengan penyelenggaraan makanan cenderung lebih banyak mengonsumsi pangan sumber zat besi seperti daging, susu, bayam, serta daun katuk.

Keragaan tingkat kecukupan energi dan zat gizi menunjukkan bahwa kelompok subjek dengan pelayanan makanan, cenderung memiliki tingkat kecukupan energi dan zat gizi yang lebih baik dibandingkan kelompok subjek tanpa pelayanan pada hari sekolah. 


\section{DAFTAR PUSTAKA}

Aprillia BA. 2011. Faktor yang Berhubungan dengan Pemilihan Makanan Jajanan pada Anak Sekolah Dasar. Artikel Penelitian. Semarang : Program Studi Ilmu Gizi, Undip.

Arteaga A, Heflin C. 2014. Participation in the National School Lunch Program and food security: An analysis of transitions into kindergarten. Children and Youth Services Review 47(2014): 224-230.

Briefel RR, Wilson A, Gleason PM.2009. Consumption of low-nutrient, energy-dense foods and beverages at school, home, and other locations among school lunch participants and nonparticipants. J Am Diet Assoc 109(2): S79-S90.

Condon EM, Crepinsek MK, Fox MK.2009. School meals: Types of foods offered to and consumed by children at lunch and breakfast. J Am Diet Assoc 109(2): S67S78.

Evans CEL, Christian MS, Cleghorn CL, Greenwood DC, Cade JE. 2012. Systematic Review and meta-analysis of school-based interventions to improve daily fruit and vegetable intake in children aged 5 to $12 \mathrm{y}$. Am J Clin Nutr 96(4): 889-901.

Farris AR, Misyak S, Duffey KJ, Davis GC, Hosig K, Atzaba-Poria N, McFerren MM, Serrano EL. 2014. Nutritional comparison of packed and school lunches in prekindergarten and kindergarten children following the implementation of the 20122013 national school lunch program standards. J Nutr Educ Behav 46(6): 621-626.

Hovland JA, Williams KJ, Hossler C, Linnenkohl S, Gould MK. 2012. Success of an early nutrition education program on kindergarten and first grade students' nutrition knowledge and behavior. Journal of the Academy of Nutrition and Dietetics 112(9).

Hu C, Ye D, Li Y, Huang Y, Li L, Gao Y, Wang S. 2009. Evaluation of a kindergarten-based nutrition-education intervention for preschool children in China. Public Health Nutrition 13(2): 253-260.

Ishida H. 2015. Role of school meal service in nutrition. J Nutr Sci Vitaminol 61: S20S22.

Jomaa LH, McDonnel E, Probart C. 2011. School feeding program in developing countries: impacts on children's health and educa- tional outcomes. Nutr (Rev. Feb) 69(2):8398.

[Kemenkes] Kementrian Kesehatan RI. 2014. Pedoman Gizi Seimbang. Jakarta: Kemenkes RI.

Lee MS, Lee JY, Yoon SH. 2006. Assessment of foodservice management performance at child care centers. Korean J Community Nutrition 11(2): 229-239.

Lynch M. 2015. Kindergarten food familiarization. An exploratory study of teachers' perspectives on food and nutrition in kindergartens. Appetite 87: 46-55.

Mohammad A, Madanijah S. 2015. Konsumsi buah dan sayur anak usia sekolah dasar di Bogor. J Gizi Pangan 10(1):70-76.

Oh SM, Yu YL, Choi HI, Kim KW. 2012. Implementation and evaluation of nutrition education programs focusing on increasing vegetables, fruits and dairy foods consumption for preschool children. Korean J Community Nutrition 17(5): 517-529.

Osera T. 2016. Nutrition education in the classroom utilizing my plate improves children's knowledge of food groups and preferences in kindergarten. J Nutr Educ Behav 48(7S):66.

Rahmi AA, Muis SF. 2005. Kontribusi makanan jajanan terhadap tingkat kecukupan energi dan protein serta status gizi anak Sekolah Dasar Siliwangi Semarang. Media Medika Muda 1:55-59.

Rakhmawati L. 2009. Kontribusi makanan di sekolah dan tingkat kecukupan energi dan zat gizi pada anak usia sekolah dasar di kota Bogor [skripsi]. Bogor: Departemen Gizi Masyarakat, IPB.

Robertson T. 2016. Building healthier kindergarten students through nutrition education. $\mathrm{J}$ Nutr Educ Behav 48(7S):82.

Santoso S, Ranti AL. 2004. Kesehatan \& Gizi. Jakarta: Rineka Cipta.

Schindler JM, Corbett D, Forestell CA. 2013. Assessing the effect of food exposure on children's identification and acceptance of fruit and vegetables. Eating Behaviors 14(1):53-56.

Sinaga T. 2007. Penyelenggaraan Makanan Anak Sekolah. Diktat Pelatihan Gizi untuk Anak Sekolah. Jakarta: Yayasan Gizi Kuliner.

Sinaga T, Kusharto CM, Setiawan B, Sulaeman A. 2012. Dampak menu sepinggan terhadap konsumsi dan tingkat kecukupan energi dan zat gizi lain pada siswa SD. J Gizi Pangan 7(1):27-34. 
Nurhidayati dkk.

Spence S, Delve J, Stamp E, Matthews JNS, White M, Adamson AJ. 2013. The impact of food and nutrient-based standards on primary school chidren's lunch and total dietary intake: A natural experimental evaluation of government policy in England. Plos one 8(10):1-8.
Tanaka N, Miyoshi M. 2012. School lunch program for health promotion among children in Japan. Asia Pac J Clin Nutr 21(1):155158.

Woo TJ. 2015. The school meal system and school-based nutrition education in Korea. J Nutr Sci Vitaminol 61(S):23-24. 